\title{
Redaktionelle Mitteilungen
}

$616,314-089.23(05)(43)$

Bei Gelegenheit der Internationalen Kongresse in London und Paris hatte die Schriftleitung Gelegenheit, mit führenden Orthodontisten der verschiedensten Länder über den Ausbau der ,Fortschritte der Orthodontik“ Fühlung zu nehmen. Von allen Seiten wurde der Plan eines regen internationalen Gedanken- und Erfahrungsaustausches lebhaft begrüßt, aber gleichzeitig eine stärkere Durchsetzung der Texte mit rerschiedensprachlichen $\mathrm{Zu}$ sammensetzungen für notwendig erachtet. Dieses Ziel wird schon in den nächsten Heften in ständig zunehmendem Umfang versucht werden.

Zur Erleichterung der Lektüre werden die französischen Übersetzungen mit einem +, die englischen mit einem $O$ gekennzeichnet werden. Falls sie im laufenden Text stehen, geschieht die Markierung durch einen dicken bzw. zwei dünne Striche an Rande.

$$
\begin{aligned}
& \text { Französischer Text }+ \text { bzw. } \\
& \text { Englischer Text } O \text { bzw. }
\end{aligned}
$$

Es sei ferner darauf hingewiesen, daß die Anschrift eines jeden Autors am Ende der betreffenden Arbeit angegeben ist. Für den Fall eines brieflichen Verkehrs der Leser mit dem Autor wird gebeten, diese Anschrift zu benutzen.

\section{Note de la Rédaction}

+ A l'occasion des Congrès Internationaux de Londres et de Paris, le rédacteur a pu s'entretenir du développement de la revue "Die Fortschritte der Orthodontik" avec les orthodontistes les plus éminents de divers pays. De toutes parts on a accueilli avec empressement le plan d'un échange international actif de pensée et d'expérience, mais en mème temps on a considéré comme indispensable d'augmenter considérablement dans le texte les portions composées dans les diverses langues. Ce but sera poursuivi dans les prochains numéros d'une façon progressive.

Pour faciliter la lecture, les traductions françaises se distingueront par le signe + et les traductions anglaises par $O$. Lorsque ces traductions se trovveront dans le texte courant, les signes distinctifs seront respectivement un trait fort ou deux traits fins dans la marge.

$$
\begin{aligned}
& \text { Texte français }+ \text { ou } \\
& \text { Texte anglais } O \text { ou } \|
\end{aligned}
$$

De plus l'attention du lecteur est attirée sur l'adresse de chacun des auteurs qui est indiquée à la fin de leurs travaux respectifs. Dans le cas d'une communication épistolaire des lecteurs avec l'auteur l'on est prié d'utiliser cette adresse.

\section{Editor's note}

O During the International Congresses in London and Paris. the editor had occasion to get into touch with the leading orthodontists of widely varied lands and find out their feeling as to the development of the Journal "Die Fortschritte der Orthodontik". On all sides the plan of a lively international exchange of thought and of experience was heartily welcomed, but at the same time the necessity was pointed out of considerably enlarging the parts set up in foreign languages in the text. In the succeding issues this goal will be aimed at gradually more extensively.

To facilitate reading. the French translations will be indentified by a + and the English by a $O$. When these translations occur in the current text they will be marked respectively by one thick or two thin lines.

$$
\begin{aligned}
& \text { French text }+ \text { or } \\
& \text { English text } O \text { or } \|
\end{aligned}
$$

Furthermore, attention is called to the address of the authors given at the end of their respective works. In case of communications by letter from reader to author, kindly use this address. 